\title{
Effects of altering total mixed ration conservation method when feeding dry-rolled versus steam-flaked hulled rice on lactation and digestion in dairy cows
}

\author{
M. Miyaji ${ }^{* 1}$ and K. Nonaka† \\ *Hokkaido Agricultural Research Center, National Agriculture and Food Research Organization (NARO), Sapporo, Hokkaido, 062-8555, Japan \\ †Institute of Livestock and Grassland Science, NARO, Nasushiobara, Tochigi, 329-2793, Japan
}

\begin{abstract}
We evaluated the effects of different methods of conserving the total mixed ration (TMR) and processing hulled rice (Oryza sativa L.) on intake, digestion, ruminal fermentation, lactation performance, and nitrogen utilization in dairy cows. Eight multiparous Holstein cows $(126 \pm 19 \mathrm{~d}$ in milk) were used in a replicated 4 $\times 4$ Latin square design with a $2 \times 2$ factorial arrangement of dietary treatments. The experimental diets used fresh TMR and ensiled TMR containing either dry-rolled (DR) hulled rice or steam-flaked (SF) hulled rice. The fresh TMR was prepared every morning. The ensiled TMR was prepared by baling fresh TMR and then sealing it with a bale wrapper; this was stored outdoors at 10 to $30^{\circ} \mathrm{C}$ for $>4$ mo. The method of grain processing did not affect the dry matter (DM) intake. The DM intake tended to be greater for ensiled TMR than for fresh TMR. Apparent total-tract DM digestibility and milk yield were increased by feeding ensiled TMR instead of fresh TMR and by replacing DR with SF. An interaction effect between the TMR conservation method and the grain processing method was detected for DM digestibility and milk yield; replacing DR with SF increased the DM digestibility and milk yield in cows fed fresh TMR, but this did not affect the cows fed ensiled TMR. The milk fat and lactose contents did not differ among dietary treatments. The milk protein concentration was higher for the cows fed SF processed hulled rice than those fed DR, but it was not influenced by the TMR conservation method. The ruminal total volatile fatty acid concentration was higher for the cows fed ensiled TMR compared with those fed fresh TMR, but it was not affected by the grain processing method. The molar proportion of acetate was decreased and propionate was increased by feeding ensiled TMR instead of fresh TMR and by replacing DR with SF.
\end{abstract}

Received September 8, 2017.

Accepted February 1, 2018.

${ }^{1}$ Corresponding author: mmiyaji@affrc.go.jp
The concentrations of rumen ammonia $\mathrm{N}$ and plasma urea $\mathrm{N}$ were higher for the cows fed ensiled TMR than fresh TMR and were lower for SF than DR. Feeding ensiled TMR instead of fresh TMR increased the cows' urinary $\mathrm{N}$ excretion and decreased the retention $\mathrm{N}$. Replacing DR with SF decreased the urinary N excretion, increased the milk $\mathrm{N}$ secretion, and then improved the nitrogen efficiency. These results show that feeding ensiled TMR instead of fresh TMR has an adverse effect on $\mathrm{N}$ utilization, but it increases digestion and milk production. Replacing DR with SF also increases digestion, milk yield, and milk protein content, and the improvement of milk yield by replacing DR with SF was prominent in the cows fed fresh TMR.

Key words: ensiled total mixed ration, milk production, nitrogen balance, nutrient digestibility, processing method

\section{INTRODUCTION}

The practice of using ensiled TMR instead of fresh TMR as a dairy cow diet is increasing in Japan, along with an increase in the number of TMR centers, which are organizations that produce ensiled TMR and deliver it to neighboring dairy farmers. Ensiled TMR, which is prepared by ensiling fresh TMR, has several advantages such as the supply of homogeneous feed over time to cows, labor savings during the preparation of TMR, the opportunity to include wet food by-product, and improved aerobic stability (Nishino et al., 2003; Wang and Nishino, 2008; Xu et al., 2007, 2010). Because of these advantages, the practice of using ensiled TMR is increasing not only in Japan, but also in China and Israel (Weinberg et al., 2011; Yuan et al., 2015). Cao et al. (2010) reported that ensiled TMR increased nutrient digestibility and the digestible energy content compared with fresh TMR. It is thus possible that increasing nutrient digestibility by feeding ensiled TMR instead of fresh TMR could improve dairy cow lactation performance.

However, the ruminal degradation characteristics of TMR are changed by ensiling. The rapidly degradable 
fraction and effective ruminal degradability of $\mathrm{CP}$ and starch increase during storage (Miyaji et al., 2017b). Miyaji et al. (2017a) suggested that increasing the rumen-digestible $\mathrm{CP}$ in diets could increase the excess $\mathrm{N}$ not used for microbial protein synthesis and increase the urinary $\mathrm{N}$ loss, because rumen-digestible $\mathrm{CP}$ that is not synthesized into microbial protein is absorbed from the rumen, converted to urea in the liver, and recycled to the gastrointestinal tract or excreted in urine (McDonald et al., 1995; Recktenwald et al., 2014; Mutsvangwa et al., 2016). In addition, some researchers have reported that increasing the rumen-digestible starch in the diets of cows resulted in depressions of DMI and decreased productivity among the cows (Oba and Allen, 2003; Miyaji et al., 2014). Thus, these adverse effects of feeding ensiled TMR on DMI and N utilization could occur.

Rice grain (Oryza sativa L.) is produced in many of the world's regions and may be an option as a dietary starch source in the future. The cultivation of rice, rather than of corn, barley, and wheat, is appropriate for the humid climates of East Asia, including Japan. Although the production of rice is increasing because of technology, the consumption has been reduced due to a population decrease and the westernization of food culture in some regions. Especially in Japan, hulled rice has recently begun to be used in dairy cow diets, and the cultivation area of rice grain for feed has been increasing.

The use of grain starch varies with the grain processing method (Dehghan-Banadaky et al., 2007). The dry-roll (DR) and steam-flake (SF) methods are the common techniques used to process grain as cold and hot physical processing methods, respectively. The SF process, which uses moisture, heat, and pressure, increases the gelatinization of starch granules (Dehghan-Banadaky et al., 2007) and thus increases the digestibility of starch (Svihus et al., 2005). Zinn et al. (1996) and Plascencia et al. (1998) reported that ruminal starch digestibility was higher for SF than for DR processing. In rice grain, the processing method has a large effect on ruminal degradation, and SF treatment is the effective method to digest starch; the effective ruminal degradability of starch is higher for SF than for cold physical processing methods such as DR and ground (Miyaji et al., 2010). Increasing the fermentable starch in the diet decreases urinary $\mathrm{N}$ losses and enhances milk production by increasing the ruminal microbial protein synthesis (Theurer et al., 1999; Krause et al., 2002; Miyaji et al., 2014). Thus, the SF processing of hulled rice could improve starch utilization, and then feeding SF-processed hulled rice instead of DR-processed hulled rice could improve dairy cow lactation performance and $\mathrm{N}$ utilization.
The objective of present study was to determine the effect of cold and hot physical processing methods for hulled rice on DMI, milk production, nutrient digestibility, $\mathrm{N}$ balance, ruminal fermentation characteristics, and blood metabolites in dairy cows fed fresh or ensiled TMR. Our hypothesis was that the TMR conservation method and grain processing method would influence nutrient digestibility, lactation performance, and $\mathrm{N}$ utilization. We expected that greater rumen-digestible starch from ensiled TMR or SF-processed hulled rice would increase milk production and nutrient digestion and improve $\mathrm{N}$ utilization compared with fresh TMR or DR-processed hulled rice. Alternatively, we speculated that increasing the rumen-digestible $\mathrm{CP}$ due to TMR ensiling could increase the urinary $\mathrm{N}$ loss.

\section{MATERIALS AND METHODS}

\section{Cows, Diets, and Management}

All animal studies were conducted in accordance with the animal care and use guidelines of the NARO Institute of Livestock and Grassland Science of Japan. Eight multiparous Holstein cows $(3.1 \pm 0.6$ parity, 640 $\pm 26 \mathrm{~kg}$ of $\mathrm{BW}, 126 \pm 19 \mathrm{DIM}$; $\pm \mathrm{SD}$ ) were randomly assigned to a replicated $4 \times 4$ Latin square design with a $2 \times 2$ factorial arrangement of dietary treatments. The experimental period was $21 \mathrm{~d}$, with $14 \mathrm{~d}$ for treatment adaptation and $7 \mathrm{~d}$ for data collection. Treatments were the conservation method of TMR (fresh vs. ensiled TMR) and the processing method of grain (DR vs. SF). The experimental diets contained either DR or SF hulled rice at $33.5 \%$ of dietary DM and were supplemented with rye silage, beet pulp, soybean meal, vitamin mix, and mineral mix (Table 1). The DR grains were prepared by passing whole hulled rice through rollers without steaming. The SF grains were prepared by steaming whole hulled rice under atmospheric pressure at $100^{\circ} \mathrm{C}$ for $30 \mathrm{~min}$ in a chamber before passing through rollers. The particle size distribution of processed grains was measured by sieving using a sieve shaker (AS200; Retsch GmbH, Haan, Germany). Sieves with 5.60-, 4.00-, 2.00-, 1.40-, $1.00-, 0.50-, 0.25-$, and $0.125-\mathrm{mm}$ openings were used. The percentages of DR particles retained on each sieve were $0.0,16.8,44.8,19.0,13.8,4.2,0.5,0.5$, and $0.4 \%$, and those of SF were 32.4, 38.3, 24.9, 2.5, 0.9, 0.6, $0.3,0.2$, and $0.0 \%$, on sieves with openings of 5.60 , $4.00,2.00,1.40,1.00,0.50,0.25$, and $0.125 \mathrm{~mm}$ and on a pan, respectively. The densities of grains were measured in triplicate by weighing a standard volume $(2 \mathrm{~L})$ of processed grains. The volume weights of DR and SF were 66.5 and $59.3 \mathrm{~kg} / 100 \mathrm{~L}$, respectively. The 
processing index of $\mathrm{DR}$ and $\mathrm{SF}$, which is expressed as the volume weight after processing as a proportion of the volume weight before processing, were 86.6 and 77.2, respectively. All experimental diets were formulated to meet or exceed the Japanese Feeding Standard for Dairy Cattle (NARO, 2006). The diets were fed as either fresh (unensiled) TMR or ensiled TMR. The TMR were prepared by mixing the feed ingredients in a Unifast vertical mixer feeder (M10 Unifeed vertical; Unifast, Settimo, Torinese, Italy). The fresh TMR was prepared every morning. The ensiled TMR was prepared by ensiling baled TMR over 4 mo in anaerobic conditions. The TMR was baled in roll form using a round baler for chopped material (TSB1000; IHI STAR Machinery, Chitose, Japan), and this baled TMR was wrapped with 8 layers of polyethylene film using a bale wrapper (SW1010; Takakita, Nabari, Japan) and then stored outdoors at approximately 10 to $30^{\circ} \mathrm{C}$ for over 4 mo. The same lot of feed ingredients was used for both the fresh and ensiled TMR. Throughout the experiment, the cows were kept in individual tiestalls and had free access to fresh water. The cows were offered the diets for ad libitum intake (allowing approximately $10 \%$

Table 1. Ingredient proportions, chemical composition, and fermentation characteristics of experimental $\mathrm{TMR}^{1}$

\begin{tabular}{|c|c|c|c|c|}
\hline \multirow[b]{2}{*}{ Item } & \multicolumn{2}{|c|}{ Fresh TMR } & \multicolumn{2}{|c|}{ Ensiled TMR } \\
\hline & DR & $\mathrm{SF}$ & DR & $\mathrm{SF}$ \\
\hline \multicolumn{5}{|l|}{ Ingredient, $\%$ of $\mathrm{DM}$} \\
\hline Rye silage & 50.1 & 50.1 & 50.1 & 50.1 \\
\hline Dry-rolled hulled rice & 33.5 & 0.0 & 33.5 & 0.0 \\
\hline Steam-flaked hulled rice & 0.0 & 33.5 & 0.0 & 33.5 \\
\hline Beet pulp & 11.3 & 11.3 & 11.3 & 11.3 \\
\hline Soybean meal & 4.1 & 4.1 & 4.1 & 4.1 \\
\hline Vitamin $\operatorname{mix}^{2}$ & 0.5 & 0.5 & 0.5 & 0.5 \\
\hline Mineral $\operatorname{mix}^{3}$ & 0.5 & 0.5 & 0.5 & 0.5 \\
\hline \multicolumn{5}{|l|}{ Chemical composition } \\
\hline DM, \% & 56.3 & 56.2 & 56.0 & 55.7 \\
\hline $\mathrm{OM}, \%$ of $\mathrm{DM}$ & 94.0 & 93.8 & 93.2 & 93.3 \\
\hline $\mathrm{CP}, \%$ of $\mathrm{DM}$ & 16.2 & 16.1 & 16.2 & 16.2 \\
\hline $\mathrm{SCP},{ }^{4} \%$ of $\mathrm{DM}$ & 5.9 & 6.0 & 7.9 & 8.0 \\
\hline Ether extract, $\%$ of DM & 2.7 & 2.8 & 2.7 & 2.7 \\
\hline $\mathrm{NDF}, \%$ of DM & 32.6 & 32.4 & 33.2 & 33.1 \\
\hline $\mathrm{ADF}, \%$ of $\mathrm{DM}$ & 18.9 & 18.9 & 19.6 & 19.3 \\
\hline Starch, \% of DM & 28.7 & 28.6 & 27.7 & 27.1 \\
\hline \multicolumn{5}{|l|}{ Fermentation profile } \\
\hline $\mathrm{pH}$ & 5.33 & 5.33 & 4.47 & 4.42 \\
\hline Lactic acid, $\%$ of DM & 2.50 & 2.48 & 6.77 & 7.19 \\
\hline Acetic acid, \% of DM & 0.30 & 0.30 & 1.15 & 1.16 \\
\hline Propionic acid, $\%$ of DM & 0.09 & 0.07 & 0.13 & 0.12 \\
\hline Butyric acid, $\%$ of DM & 0.01 & 0.02 & 0.03 & 0.03 \\
\hline Volatile basic $\mathrm{N}, \%$ of DM & 0.04 & 0.04 & 0.08 & 0.07 \\
\hline
\end{tabular}

refusals) twice daily (0900 and $1900 \mathrm{~h}$ ) and were milked in their stalls twice daily (0830 and $1830 \mathrm{~h}$ ).

\section{Data and Sample Collection}

From d 15 to 20 of each period, the amount of feed offered and orts were weighed and representative samples were collected daily. Each TMR sample was stored at $-30^{\circ} \mathrm{C}$ for the later determination of its chemical composition and fermentation products. The ort samples were pooled, and one sample was retained per cow per period. The TMR samples were freeze-dried, and the ort samples were dried at $60^{\circ} \mathrm{C}$ in an oven for $48 \mathrm{~h}$. The dried samples were ground through a 1-mm screen using a centrifugal mill (ZM200; Retsch GmbH) and stored until analysis. The milk yield was measured daily and averaged over the collection period, and duplicate milk samples were taken at every milking. One set of duplicate samples was analyzed for fat, CP, lactose, and urea- $\mathrm{N}$ concentrations by infrared spectroscopy (Milko-Scan 133B; N. Foss Electric, Hillerød, Denmark; AOAC International, 2000). The second set of samples was refrigerated until the end of each collection period, composited by cow within the period according to daily milk yield, and frozen at $-30^{\circ} \mathrm{C}$ until $\mathrm{N}$ analysis.

On d 15 to 20 of each period, we determined the whole-tract apparent digestibility and $\mathrm{N}$ balance by the total collection of feces and urine, using an automatic feces-urine separating machine that was equipped with a continuous-running one complete cycle belt and the scraper blade to collect feces and urine separately (Miyaji et al., 2017a). All feces were collected daily in buckets. The total weight of the daily feces was measured, and a portion of $5 \%$ of the total weight was then stored at $-20^{\circ} \mathrm{C}$ during the collection period. Just after collection, the feces samples were mixed well. A portion of fresh feces was dried at $60^{\circ} \mathrm{C}$ for at least $72 \mathrm{~h}$ in a forced-air oven followed by grinding through a 1-mm screen, and the other portion was used for the analysis of the DM and total N. All urine was collected daily in plastic buckets containing $250 \mathrm{~mL}$ of $20 \%$ sulfuric acid that had been added to achieve a urine $\mathrm{pH}$ of $<3.0$. The total weight of the urine was measured, and a sample of $5 \%$ of the total weight was stored in a refrigerator at $5^{\circ} \mathrm{C}$ during the collection. Just after collection, the urine samples were mixed well and stored at $-30^{\circ} \mathrm{C}$ until analysis.

Ruminal fluid was collected via an esophageal tube using a rumen catheter (Sanshin Industrial, Yokohama, Japan) at 0 (just before the morning feeding), 3 , and 6 $\mathrm{h}$ after the morning feeding on $\mathrm{d} 21$ of each period. The ruminal fluids were separated from the feed particles through 4 layers of gauze and centrifuged at 3,500 $\times \mathrm{g}$ for $15 \mathrm{~min}$ at $5^{\circ} \mathrm{C}$. For the determination of VFA and 
ammonia $\mathrm{N}$, we added $1 \mathrm{~mL}$ of $30 \%$ perchloric acid solution as a deproteinizing agent to $4 \mathrm{~mL}$ of ruminal fluid, and the resultant fluid samples were then stored at $-30^{\circ} \mathrm{C}$ until analysis. Blood samples were collected into heparinized tubes from the jugular vein of each cow at 0 and $3 \mathrm{~h}$ after the morning feeding on $\mathrm{d} 21$ of each period. The samples were immediately centrifuged at $3,500 \times g$ for $15 \mathrm{~min}$ at $5^{\circ} \mathrm{C}$, and the plasma was stored at $-30^{\circ} \mathrm{C}$ until the urea- $\mathrm{N}$ and glucose analysis. The ruminal fluid and plasma samples were analyzed without compositing per each sampling time.

\section{Chemical Analysis}

The DM of the feed and orts was determined by drying the sample at $105^{\circ} \mathrm{C}$ for $24 \mathrm{~h}$. The wet fecal samples were dried at $135^{\circ} \mathrm{C}$ for $2 \mathrm{~h}$ after drying at $60^{\circ} \mathrm{C}$ for 24 $\mathrm{h}$. Wet feces were used for the analysis of nitrogen. The $\mathrm{OM}$ was calculated as the difference between the DM and ash contents after the ash determination by the AOAC method (AOAC International, 2000, method 942.05). The ether extract and Kjeldahl $\mathrm{N}$ values were determined by the AOAC method (AOAC International, 2000, methods 920.39 and 990.03, respectively). The total buffer-soluble CP (SCP) was determined by incubating the sample with bicarbonate-phosphate buffer and filtering through Whatman \#54 filter paper (Roe et al., 1990). The NDF and ADF (NDF assayed with a heat-stable amylase, sodium sulfite and expressed exclusive of residual ash; ADF expressed exclusive of residual ash) were analyzed by the methods of Van Soest et al. (1991). The starch was analyzed using a starch assay kit (Megazyme International Ireland, Wicklow, Ireland; McCleary et al., 1994). The urine and milk samples were analyzed for Kjeldahl $\mathrm{N}$ with the same methodology as that used for the feeds.

The fermentation products of the TMR were determined from cold-water extracts. Wet TMR (60 g) was homogenized with $140 \mathrm{~mL}$ of sterilized distilled water and stored at $4^{\circ} \mathrm{C}$ overnight (Cai et al., 1999). The $\mathrm{pH}$ was measured with a glass electrode $\mathrm{pH}$ meter (D-51; Horiba, Irvine, CA), and volatile basic nitrogen (VBN) was determined by steam distillation of the filtrates. The organic acid contents were measured by HPLC (Hosoda et al., 2006).

The samples of deproteinized ruminal fluid were neutralized with potassium hydroxide solution and centrifuged at $3,500 \times g$ for $10 \mathrm{~min}$ at $5^{\circ} \mathrm{C}$. The supernatants were shaken with a cation exchange resin (Amberlite, IR 120B H AG; Organo, Tokyo) and centrifuged at 10,000 $\times g$ for $5 \mathrm{~min}$ at $5^{\circ} \mathrm{C}$. The supernatants were used for the analysis of lactic acid and VFA using HPLC as they were for the TMR filtrates, and for the analysis of
ammonia-N (Weatherburn, 1967). Urea-N and glucose in plasma were measured with an automatic analyzer (7080 Clinical Analyzer, Hitachi, Tokyo, Japan).

\section{Statistical Analysis}

The data for all variables were analyzed using the MIXED procedure of SAS software (SAS Institute Inc., Cary, NC). The data on DMI, milk yield, milk composition, digestibility, and $\mathrm{N}$ balance were analyzed as a replicated $4 \times 4$ Latin square design with a $2 \times$ 2 factorial treatment arrangement using the following model: $Y_{i j k l m}=\mu+a_{i}+b_{j}+c_{k}\left(a_{i}\right)+d_{l}+e_{m}+d_{l} \times$ $e_{m}+\varepsilon_{i j k l m}$, where $Y_{i j k l m}$ is the dependent variable, $\mu$ is the overall mean, $a_{i}$ is the fixed effect of square $(i=1$ to 2$), b_{j}$ is the fixed effect of period ( $j=1$ to 4$), c_{k}\left(a_{i}\right)$ is the random effect of cow within square $(k=1$ to 8$)$, $d_{l}$ is the fixed effect of the TMR conservation method ( $l$ $=1$ to 2 ; fresh TMR vs. ensiled TMR), $e_{m}$ is the fixed effect of the grain processing method ( $m=1$ to 2 ; DR vs. SF), $d_{l} \times e_{m}$ is the fixed effect of the interaction of $d_{l}$ and $e_{m}$, and $\varepsilon_{i j k l m}$ is the residual error. Measurements of the ruminal fermentation parameters and the plasma concentration were analyzed as repeated measures by adding fixed effects of sampling times and their interaction with the TMR conservation and grain processing methods to the previous model. A first-order autoregressive was the best covariance structure based on the smallest Akaike's information criterion values. Other covariance structures tested included compound symmetry, heterogeneous autoregressive 1, heterogeneous compound symmetry, and unstructured. Significance was declared at $P<0.05$.

\section{RESULTS}

\section{Diet Characteristics}

The chemical composition and fermentation profiles of DR and SF were similar (Table 1). Our comparison of fresh TMR with ensiled TMR revealed little difference in the chemical composition except for the starch, fiber, and SCP contents, with slight decreases in starch content and increases in fiber and SCP contents during ensiling. The dietary $\mathrm{pH}$ was decreased and the lactic acid and acetic acid concentrations were increased due to TMR ensiling, regardless of the grain processing method.

\section{DMI and Whole-Tract Digestibility}

No significant interaction between TMR conservation and grain processing methods was detected in DMI 
(Table 2). The method of hulled rice processing did not affect DMI. The DMI tended to be greater for ensiled TMR than for fresh TMR $(P=0.06)$. A significant interaction between the TMR conservation method and the grain processing method was detected for the DM $(P=0.01), \mathrm{OM}(P=0.01)$, and starch digestibilities $(P$ $<0.01)$; replacing DR with $\mathrm{SF}$ increased the DM and OM digestibilities in the cows fed fresh TMR, but this replacement did not affect the cows fed ensiled TMR. No significant interactions existed between the TMR conservation and grain processing methods in nutrient digestibility except for that of $\mathrm{OM}$ and starch. The feeding of ensiled TMR instead of fresh TMR significantly increased the whole-tract apparent digestibility of the DM $(P<0.01)$, OM $(P<0.01)$, ether extract $(P<0.01)$, NDF $(P<0.01)$, and starch $(P<0.01)$. The TMR conservation method did not affect the CP or ADF digestibilities. The grain processing method affected the nutrient digestibility except for that of CP. Replacing DR with SF significantly increased the DM $(P<0.01)$, OM $(P<0.01)$, ether extract $(P<0.01)$, and starch digestibilities $(P<0.01)$, but conversely, it significantly decreased the NDF $(P<0.01)$ and ADF digestibilities $(P<0.01)$.

\section{Ruminal Fermentation Characteristics and Plasma Metabolites}

No significant interactions existed between the dietary treatments and sampling time in any of the ruminal fermentation characteristics or plasma metabolites. Dietary treatment did not influence the rumen lactic acid concentration (Table 3). Feeding of ensiled TMR instead of fresh TMR increased the total VFA concentration $(P=0.01)$. The grain processing method did not affect the total VFA concentration. The molar proportions of acetate $(P<0.01)$ and butyrate $(P<0.01)$ were significantly lower and those of propionate $(P<0.01)$, isovalerate $(P<0.01)$, and valerate $(P<0.01)$ were significantly higher for the cows fed ensiled TMR compared with the cows fed fresh TMR. The grain processing method affected the molar proportions of acetate $(P<0.01)$, propionate $(P<0.01)$, isobutyrate $(P=0.03)$, and butyrate $(P=$ $0.01)$ : molar proportion of acetate was decreased and of propionate and butyrate were increased by replacing DR with SF. A significant $(P<0.01)$ interaction between dietary treatments in the plasma urea $\mathrm{N}$ concentration was detected: replacing DR with SF decreased the plasma urea $\mathrm{N}$ concentration in the cows fed fresh TMR, but this replacement did not affect the cows fed ensiled TMR. The concentrations of rumen ammonia $\mathrm{N}$ and plasma urea $\mathrm{N}$ were significantly increased by replacing fresh TMR with ensiled TMR $(P$ $=0.03$ and $P<0.01$, respectively) and significantly decreased by replacing DR with SF $(P=0.048$ and $P<0.01$, respectively). Feeding ensiled TMR instead of fresh TMR $(P=0.03)$ and replacing DR with SF $(P=0.04)$ significantly increased the plasma glucose concentration.

\section{Milk Production}

Feeding SF instead of DR increased the milk yield under fresh TMR but not under ensiled TMR, leading to a TMR conservation $\times$ grain processing interaction (Table $4, P=0.01)$. Feeding ensiled TMR instead of fresh TMR $(P<0.01 ; 37.6$ vs. $36.4 \mathrm{~kg} / \mathrm{d})$ and using SF instead of DR $(P=0.01 ; 37.5$ vs. $36.5 \mathrm{~kg} / \mathrm{d})$ increased milk yield. The milk fat yield was similar across dietary

Table 2. Effect of TMR conservation method and grain processing method $^{1}$ on DMI and whole-tract digestibility in dairy cows

\begin{tabular}{|c|c|c|c|c|c|c|c|c|}
\hline \multirow[b]{2}{*}{ Item } & \multicolumn{2}{|c|}{ Fresh TMR } & \multicolumn{2}{|c|}{ Ensiled TMR } & \multirow[b]{2}{*}{ SEM } & \multicolumn{3}{|c|}{ Significance of effect ${ }^{2}$} \\
\hline & DR & $\mathrm{SF}$ & DR & $\mathrm{SF}$ & & $\mathrm{TC}$ & GP & $\mathrm{TC} \times \mathrm{GP}$ \\
\hline $\begin{array}{l}\text { DMI, kg/d } \\
\text { Digestibility, \% }\end{array}$ & 22.3 & 22.5 & 23.0 & 23.0 & 0.66 & 0.06 & 0.61 & 0.63 \\
\hline DM & $70.4^{\mathrm{c}}$ & $74.2^{\mathrm{b}}$ & $77.1^{\mathrm{a}}$ & $78.1^{\mathrm{a}}$ & 0.34 & $<0.01$ & $<0.01$ & 0.01 \\
\hline $\mathrm{OM}$ & $71.9^{\mathrm{c}}$ & $75.8^{\mathrm{b}}$ & $78.9^{\mathrm{a}}$ & $80.0^{\mathrm{a}}$ & 0.34 & $<0.01$ & $<0.01$ & 0.01 \\
\hline $\mathrm{CP}$ & 62.3 & 62.6 & 63.4 & 61.7 & 1.62 & 0.56 & 0.25 & 0.15 \\
\hline Ether extract & 62.6 & 68.2 & 79.6 & 80.9 & 1.38 & $<0.01$ & $<0.01$ & 0.12 \\
\hline $\mathrm{NDF}$ & 68.1 & 64.9 & 71.2 & 70.2 & 0.87 & $<0.01$ & $<0.01$ & 0.07 \\
\hline $\mathrm{ADF}$ & 71.2 & 68.3 & 70.1 & 68.4 & 0.58 & 0.67 & $<0.01$ & 0.23 \\
\hline Starch & $86.2^{\mathrm{c}}$ & $97.0^{\mathrm{ab}}$ & $95.2^{\mathrm{b}}$ & $99.2^{\mathrm{a}}$ & 1.06 & $<0.01$ & $<0.01$ & $<0.01$ \\
\hline
\end{tabular}

${ }^{a-c}$ Means within a row without a common superscript differ $(P<0.05)$.

${ }^{1} \mathrm{DR}=$ dry-rolled hulled rice; $\mathrm{SF}=$ steam-flaked hulled rice.

${ }^{2} \mathrm{TC}=$ effect of TMR conservation method (fresh TMR vs. ensiled TMR); GP = effect of grain processing method (DR vs. SF); TC $\times$ GP = interaction effect between TC and GP. 
Table 3. Effect of TMR conservation method and grain processing method ${ }^{1}$ on ruminal fermentation characteristics and plasma metabolites in dairy cows

\begin{tabular}{|c|c|c|c|c|c|c|c|c|}
\hline \multirow[b]{2}{*}{ Item } & \multicolumn{2}{|c|}{ Fresh TMR } & \multicolumn{2}{|c|}{ Ensiled TMR } & \multirow[b]{2}{*}{ SEM } & \multicolumn{3}{|c|}{ Significance of effect ${ }^{2}$} \\
\hline & DR & $\mathrm{SF}$ & DR & $\mathrm{SF}$ & & $\mathrm{TC}$ & GP & $\mathrm{TC} \times \mathrm{GP}$ \\
\hline Ammonia N, mg/dL & 8.50 & 6.04 & 8.92 & 8.69 & 1.087 & 0.03 & 0.048 & 0.10 \\
\hline Lactic acid, $\mathrm{mM}$ & 1.3 & 1.6 & 1.3 & 2.9 & 1.33 & 0.42 & 0.22 & 0.43 \\
\hline Total VFA, mM & 95.1 & 99.1 & 101.4 & 102.1 & 9.16 & 0.01 & 0.18 & 0.35 \\
\hline \multicolumn{9}{|l|}{ VFA, mol/100 mol } \\
\hline Isobutyrate & 1.1 & 1.0 & 1.1 & 1.1 & 0.00 & 0.08 & 0.03 & 0.32 \\
\hline Butyrate & 10.6 & 11.1 & 9.7 & 10.3 & 0.06 & $<0.01$ & 0.01 & 0.64 \\
\hline Isovalerate & $2.6^{\mathrm{bc}}$ & $2.3^{\mathrm{c}}$ & $2.9^{\mathrm{b}}$ & $3.5^{\mathrm{a}}$ & 0.04 & $<0.01$ & 0.54 & 0.01 \\
\hline Valerate & 1.9 & 1.9 & 2.1 & 2.1 & 0.01 & $<0.01$ & 0.79 & 0.44 \\
\hline \multicolumn{9}{|l|}{ Plasma metabolites } \\
\hline Urea-N, mg/dL & $10.3^{\mathrm{a}}$ & $8.9^{\mathrm{b}}$ & $10.5^{\mathrm{a}}$ & $10.3^{\mathrm{a}}$ & 0.11 & $<0.01$ & $<0.01$ & $<0.01$ \\
\hline Glucose, $\mathrm{mg} / \mathrm{dL}$ & 64.7 & 67.5 & 67.4 & 69.0 & 2.95 & 0.03 & 0.04 & 0.67 \\
\hline
\end{tabular}

${ }^{\mathrm{a}-\mathrm{c}}$ Means within a row without a common superscript differ $(P<0.05)$.

${ }^{1} \mathrm{DR}=$ dry-rolled hulled rice; $\mathrm{SF}=$ steam-flaked hulled rice.

${ }^{2} \mathrm{TC}=$ effect of TMR conservation method (fresh TMR vs. ensiled TMR); GP $=$ effect of grain processing method $(\mathrm{DR}$ vs. SF); TC $\times$ GP $=$ interaction effect between TC and GP.

treatments. The milk CP yield was higher for the cows fed ensiled TMR compared with those fed fresh TMR $(P<0.01)$ and higher for the cows fed SF compared with those fed DR $(P<0.01)$. The effects of dietary treatment on the milk lactose yield were similar to those observed for the milk yield. The dietary treatment did not affect the concentration of milk fat or that of lactose. The TMR conservation method did not influence the milk CP content, but the cows fed SF showed significantly increased milk CP concentrations compared with those fed DR $(P<0.01)$. Feeding SF decreased the milk urea $\mathrm{N}$ content compared with $\mathrm{DR}$ $(P<0.01)$, whereas the TMR conservation method did not affect the milk urea $\mathrm{N}$ content.

\section{Nitrogen Balance}

No significant interactions between TMR conservation and grain processing methods were observed for any of the $\mathrm{N}$ balance measurements (Table 5). The method of TMR conservation and grain processing did not affect the nitrogen intake or fecal N excretion. Feeding ensiled TMR instead of fresh TMR did not influence the milk $\mathrm{N}$ secretion, but it significantly increased the urinary $\mathrm{N}$ excretion $(P<0.01)$ and decreased the $\mathrm{N}$ retention $(P<0.01)$. The replacement of $\mathrm{DR}$ with $\mathrm{SF}$ did not affect the $\mathrm{N}$ retention, but it significantly decreased the urinary $\mathrm{N}$ excretion $(P<0.01)$ and significantly increased the milk $\mathrm{N}$ secretion $(P<0.01)$.

Table 4. Effect of TMR conservation method and grain processing method ${ }^{1}$ on milk yield and composition in dairy cows

\begin{tabular}{|c|c|c|c|c|c|c|c|c|}
\hline \multirow[b]{2}{*}{ Item } & \multicolumn{2}{|c|}{ Fresh TMR } & \multicolumn{2}{|c|}{ Ensiled TMR } & \multirow[b]{2}{*}{ SEM } & \multicolumn{3}{|c|}{ Significance of effect ${ }^{2}$} \\
\hline & DR & $\mathrm{SF}$ & DR & $\mathrm{SF}$ & & $\mathrm{TC}$ & GP & $\mathrm{TC} \times \mathrm{GP}$ \\
\hline \multicolumn{9}{|l|}{ Yield, kg/d } \\
\hline Milk & $35.4^{\mathrm{b}}$ & $37.4^{\mathrm{a}}$ & $37.6^{\mathrm{a}}$ & $37.6^{\mathrm{a}}$ & 0.41 & $<0.01$ & 0.01 & 0.01 \\
\hline Fat & 1.57 & 1.56 & 1.62 & 1.64 & 0.006 & 0.06 & 0.55 & 0.80 \\
\hline $\mathrm{CP}$ & 1.18 & 1.30 & 1.27 & 1.34 & 0.002 & $<0.01$ & $<0.01$ & 0.10 \\
\hline Lactose & $1.58^{\mathrm{b}}$ & $1.66^{\mathrm{a}}$ & $1.69^{\mathrm{a}}$ & $1.69^{\mathrm{a}}$ & 0.001 & $<0.01$ & 0.03 & 0.03 \\
\hline \multicolumn{9}{|l|}{ Milk composition } \\
\hline Fat, $\%$ & 4.45 & 4.18 & 4.31 & 4.44 & 0.038 & 0.75 & 0.13 & 0.07 \\
\hline $\mathrm{CP}, \%$ & 3.39 & 3.51 & 3.43 & 3.55 & 0.013 & 0.24 & $<0.01$ & 0.51 \\
\hline Lactose, \% & 4.45 & 4.44 & 4.50 & 4.49 & 0.002 & 0.12 & 0.72 & 0.97 \\
\hline Urea-N, mg/dL & 17.30 & 15.50 & 17.50 & 16.70 & 0.756 & 0.08 & $<0.01$ & 0.07 \\
\hline
\end{tabular}

a,b Means within a row without a common superscript differ $(P<0.05)$.

${ }^{1} \mathrm{DR}=$ dry-rolled hulled rice; $\mathrm{SF}=$ steam-flaked hulled rice.

${ }^{2} \mathrm{TC}=$ effect of TMR conservation method (fresh TMR vs. ensiled TMR); GP = effect of grain processing method (DR vs. SF); TC $\times$ GP $=$ interaction effect between TC and GP. 
Table 5. Effect of TMR conservation method and grain processing method ${ }^{1}$ on nitrogen utilization in dairy cows

\begin{tabular}{|c|c|c|c|c|c|c|c|c|}
\hline \multirow[b]{2}{*}{ Item } & \multicolumn{2}{|c|}{ Fresh TMR } & \multicolumn{2}{|c|}{ Ensiled TMR } & \multirow[b]{2}{*}{ SEM } & \multicolumn{3}{|c|}{ Significance of effect ${ }^{2}$} \\
\hline & DR & $\mathrm{SF}$ & DR & $\mathrm{SF}$ & & $\mathrm{TC}$ & GP & $\mathrm{TC} \times \mathrm{GP}$ \\
\hline \multirow{3}{*}{$\begin{array}{l}\mathrm{N} \text { intake, } \mathrm{g} / \mathrm{d} \\
\text { Milk N } \\
\mathrm{g} / \mathrm{d} \\
\%\end{array}$} & 589.0 & 589.7 & 600.2 & 597.7 & 42.60 & 0.20 & 0.65 & 0.79 \\
\hline & 185.6 & 204.9 & 200.3 & 208.2 & 28.30 & 0.05 & $<0.01$ & 0.37 \\
\hline & 31.5 & 34.7 & 33.4 & 35.0 & 1.53 & 0.17 & $<0.01$ & 0.59 \\
\hline \multicolumn{9}{|c|}{ Fecal N excretion } \\
\hline $\mathrm{g} / \mathrm{d}$ & 222.9 & 220.9 & 219.6 & 228.7 & 32.88 & 0.85 & 0.45 & 0.22 \\
\hline$\%$ & 37.7 & 37.4 & 36.6 & 38.3 & 1.62 & 0.56 & 0.25 & 0.15 \\
\hline \multicolumn{9}{|c|}{ Urinary $\mathrm{N}$ excretion } \\
\hline $\mathrm{g} / \mathrm{d}$ & 133.4 & 114.2 & 157.9 & 146.5 & 22.65 & $<0.01$ & $<0.01$ & 0.36 \\
\hline$\%$ & 22.8 & 19.5 & 26.3 & 24.5 & 2.12 & $<0.01$ & $<0.01$ & 0.26 \\
\hline \multicolumn{9}{|l|}{$\mathrm{N}$ retention } \\
\hline $\mathrm{g} / \mathrm{d}$ & 47.2 & 49.8 & 22.4 & 14.3 & 21.48 & $<0.01$ & 0.23 & 0.16 \\
\hline$\%$ & 8.0 & 8.5 & 3.7 & 2.2 & 1.05 & $<0.01$ & 0.19 & 0.13 \\
\hline
\end{tabular}

\section{DISCUSSION}

The rapidly degradable starch fraction and the effective ruminal starch degradability of TMR increase during ensiling storage (Miyaji et al., 2017b). In addition, steam flaking, which uses moisture, heat, and pressure, increases the gelatinization of starch granules (Dehghan-Banadaky et al., 2007), which leads to an increase in the ruminal starch digestibility of grain compared with the DR process (Zinn et al., 1996; Plascencia et al., 1998). Thus, in the present study the ruminal starch digestibility would be higher for ensiled TMR or SF-processed hulled rice compared with fresh TMR or DR-processed hulled rice. Some researchers suggested that DMI decreased when cows were fed a more rapidly available starch source (Krause et al., 2002; Oba and Allen, 2003), which was caused by a higher ruminal propionate concentration (Oba and Allen, 2003) and lower ruminal pH (Yang et al., 2000). In the present study, however, DMI was not decreased by replacing DR with SF and replacing fresh TMR with ensiled TMR, although the feeding of ensiled TMR or SF increased the ruminal propionate proportion compared with the feeding of fresh TMR or DR. The differences in ruminal starch degradation and ruminal fermentation characteristics between TMR conservation methods or the grain processing methods (or both) may have been too small to have had an effect on DMI. Contrary to our expectations, DMI tended to be higher for ensiled TMR than for fresh TMR. Feeds low in digestibility are thought to place constraints on DMI because of their slow clearance from the rumen (NRC, 2001). The feeding of ensiled TMR instead of fresh TMR increased the digestibility of DM, OM, and NDF. Thus, the increased digestibility due to TMR ensiling could have lowered rumen fill and could result in increased DMI.

Cao et al. (2010) reported that the ensiling process of TMR increased nutrient digestibility and the digestible energy content, which is consistent with our present findings. Miyaji et al. (2017b) suggested that the ruminal DM and starch degradability of TMR increased during ensiling, and this could be explained by the increase in the proportion of swelling starch granules (Sholly et al., 2011) or by the proteolysis that promotes the solubilization of starch granules (Peyrat et al., 2014) during the ensiling process. Thus, the promotion of the solubilization or the swelling (or both) of starch granules due to ensiling could increase the ruminal degradation and then increase the whole-tract digestibility of DM, OM, and starch. We also observed that the grain processing method affected the nutrient digestibility; digestibilities of DM, OM, and starch were increased by replacing DR with SF in our experiment. Steam flaking, in which heat and moisture are added to grain, gelatinizes starch and increases the degradation of starch by microorganisms in the rumen (Waldo, 1973) and by enzymatic digestion (Osman et al., 1970), and thus, the digestibility of starch, DM, and OM was increased by the SF process. However, a clear interaction between the TMR conservation method and the grain processing method was detected in the DM, $\mathrm{OM}$, and starch digestibility. Replacing DR with SF increased the DM, OM, and starch digestibilities in the cows fed fresh TMR, but no or small differences existed in these digestibilities between the grain processing methods in the cows fed ensiled TMR. Therefore, the SF process of hulled rice could be an effective strategy to increase nutrient digestibility (except for those 
of fiber and $\mathrm{CP}$ ) compared with the DR process, but this increment could be reduced by TMR ensiling. In the present study, the effects of the grain processing method on fiber digestibility were different from those observed for DM and starch; the digestibilities of NDF and ADF were decreased by replacing DR with SF. Some research groups reported that increasing ruminal starch digestibility by replacing the starch source resulted in fiber digestibility depression (Ferraretto et al., 2013; Miyaji et al., 2014, 2017a). Harmison et al. (1997) reported that the high rate of cereal digestion could increase the likelihood of decreasing fiber digestibility caused by lowered ruminal $\mathrm{pH}$. Although we did not measure the ruminal $\mathrm{pH}$ in the present study, we speculate that the rapid starch degradation of SF could impair the ruminal fiber fermentation and then decrease the whole-tract fiber digestibility with the replacement of DR with SF.

Cao et al. (2010) showed that the ensiling process of TMR increased the total VFA and propionate concentrations in the rumen, which is consistent with our present findings. Miyaji et al. (2017b) reported that the ruminal DM and starch degradabilities of ensiled TMR were higher than those of fresh TMR. In addition, Cao et al. (2010) suggested that the higher lactic acid content of ensiled TMR could increase the ruminal propionate production because lactic acid is used in the rumen by lactate-utilizing bacteria, and then propionate is generally produced (Dawson et al., 1997; Russell and Wallace, 1997). Thus, the increased total VFA concentration and propionate proportion achieved by replacing fresh TMR with ensiled TMR could be attributed to the greater rumen-digestible starch and lactic acid contents in ensiled TMR compared with fresh TMR. We observed herein that the method used to process hulled rice did not affect the total VFA concentration, but it changed the rumen fermentation pattern. The decreased acetate and increased propionate and butyrate that we observed when DR was replaced with SF could have been caused by the rapid starch degradability of SF compared with that of DR (Miyaji et al., 2010). The greater ruminal starch digestibility for ensiled TMR and SF could be expected to increase the ruminal lactic acid concentration. However, the ruminal lactic acid concentration did not differ among the dietary treatments, and this lactate value was low. In addition, feeding ensiled TMR instead of fresh TMR and feeding SF instead of DR did not decrease DMI. Thus, the differences in ruminal degradation characteristics between the TMR conservation method or the grain processing method could have little effect on the risk of developing ruminal acidosis. The plasma glucose concentration was also increased when feeding ensiled TMR instead of fresh TMR and when DR was replaced with SF, as was the rumen propionate proportion. The plasma glucose concentration arises largely from hepatic gluconeogenesis using ruminally derived propionate as the principal precursor (Huntington, 1997), and feeding dairy cows increased glycogenic nutrients levels increases their plasma glucose (Cabrita et al., 2007). Thus, the increase in the plasma glucose concentration could be attributed to the greater starch fermentation and the higher ruminal propionate.

In the present study, milk yield increased in response to replacement of fresh TMR with ensiled TMR and replacement of DR with SF. Feeding ensiled TMR instead of fresh TMR and replacing DR with SF increased DM digestibility. In addition, DMI tended to be greater for ensiled TMR than for fresh TMR. Thus, increasing DM digestibility and DMI by feeding ensiled TMR instead of fresh TMR and increasing DM digestibility by replacing DR with SF would increase milk yield. Our analyses also revealed significant interactions between TMR conservation method and grain processing method for milk yield; milk yield was increased by replacing DR with SF under the feeding of fresh TMR, but it was similar under the feeding of ensiled TMR. This interaction for milk yield could be linked with the interaction for DM digestibility. In the cows fed fresh TMR, the greater milk yield due to feeding SF instead of DR could be associated with increased DM digestibility. In cows fed ensiled TMR, however, DM digestibility did not differ between the 2 grain processing methods, and this lack of a difference resulted in similar milk yield. Thus, the SF process of hulled rice could be an effective strategy to increase milk production due to increased DM digestibility compared with the DR process, but this increment could be reduced by TMR ensiling. We also observed that DM digestibility and milk yield were increased by the feeding of ensiled TMR instead of fresh TMR under DR, but these were similar under SF, causing a TMR conservation and grain processing interaction. Therefore, the ensiling treatment of TMR could be an effective strategy to increase nutrient digestion and milk production, especially when using a cold physical processing method for hulled rice such as DR.

Some researchers suggested that increasing fermentable starch in the diet decreases urinary $\mathrm{N}$ losses or enhances milk protein production because of an increase in ruminal microbial protein synthesis (Theurer et al., 1999; Miyaji et al., 2014). Ruminal starch digestibility was higher for ensiled TMR than for fresh TMR (Miyaji et al., 2017b) and higher for SF than for DR processing (Zinn et al., 1996; Plascencia et al., 1998). Thus, feeding ensiled TMR instead of fresh TMR and feeding SF instead of DR could be expected to improve N utilization. However, our present findings demonstrated that replacing fresh TMR with ensiled TMR increased 
urinary $\mathrm{N}$ loss and decreased retention $\mathrm{N}$ with no effect on secreted $\mathrm{N}$ in milk or fecal $\mathrm{N}$ excretion. The SCP content was higher for ensiled TMR than for fresh TMR in the present study. Miyaji et al. (2017b) also reported that the water-soluble fraction and ruminal effective degradability of CP in a TMR were increased by the ensiling process. Rumen-digestible $\mathrm{CP}$ that is not used for microbial protein synthesis is absorbed from the rumen, converted to urea in the liver, and recycled to the rumen or excreted in urine (McDonald et al.,1995; Recktenwald et al., 2014; Mutsvangwa et al., 2016). The rumen-digestible CP content has little effect on urea- $\mathrm{N}$ recycling to the rumen (Mutsvangwa et al., 2016), and the recycled urea- $\mathrm{N}$ can support microbial growth when the dietary rumen-digestible $\mathrm{CP}$ intake is low (Lapierre and Lobley, 2001). Thus, the microbial incorporation of recycled urea- $\mathrm{N}$ into microbial protein may be lower in cows fed ensiled TMR compared with fresh TMR. Because the increases of rumen-digestible $\mathrm{CP}$ due to TMR ensiling could increase the excess $\mathrm{N}$ not used for microbial protein synthesis, feeding ensiled TMR instead of fresh TMR could increase the urinary $\mathrm{N}$ loss and not improve the $\mathrm{N}$ utilization. The higher ruminal ammonia $\mathrm{N}$ and plasma urea- $\mathrm{N}$ concentrations in cows fed ensiled TMR could support this hypothesis. On the other hand, in the present study feeding of SF instead of DR improved $\mathrm{N}$ utilization, increased milk $\mathrm{N}$ secretion, and decreased urinary $\mathrm{N}$ loss. The effective ruminal degradability of starch is higher for SFprocessed rice than for DR-processed rice (Miyaji et al., 2010). Theurer et al. (1999) suggested that the greater ruminal and total starch digestion due to SF processing of grain increased the cycling of urea to the rumen, the microbial protein reaching the small intestine, and the estimated AA uptake by the mammary glands, and then increased milk protein yield, compared with the DR processing of grain. Thus, the replacement of DR-processed hulled rice with SF-processed hulled rice could improve the ruminal $\mathrm{N}$ utilization by providing a more available starch source for microbial protein production, and this improvement could decrease the urinary $\mathrm{N}$ losses and increase the milk $\mathrm{CP}$ production in cows. The lower ruminal ammonia $\mathrm{N}$ and plasma urea-N concentrations in cows fed SF may support this hypothesis.

\section{CONCLUSIONS}

Our data demonstrated that feeding ensiled TMR increased nutrient digestibility (except for CP digestibility), tended to increase DMI, and, thus, increased milk production. However, replacing fresh TMR with ensiled TMR increased urinary $\mathrm{N}$ loss. Thus, the ensiling treatment of TMR can be an effective strategy to improve feed utilization and milk yield, but its adverse effect on $\mathrm{N}$ utilization should be considered. We also observed that feeding cows SF-processed hulled rice increased nutrient digestibility (except for fiber and CP digestibility) and milk production compared with feeding cows DR-processed hulled rice, but this increment was reduced by TMR ensiling because the increases in nutrient digestion and milk production due to TMR ensiling were greater for DR than SF. In addition, feeding of SF-processed hulled rice instead of DR-processed hulled rice decreased urinary $\mathrm{N}$ loss and thus increased milk protein composition and yield. The steam-flaking method can therefore be a good approach to process hulled rice to improve feed utilization, $\mathrm{N}$ efficiency, and milk production.

\section{ACKNOWLEDGMENTS}

The author thank the members of K. Muroi's team at the NARO Institute of Livestock and Grassland Science (Nasushiobara, Japan) for feed preparations and animal management and T. Fujita (NARO Institute of Livestock and Grassland Science) for help in collecting and analyzing the samples.

\section{REFERENCES}

AOAC International. 2000. Official Methods of Analysis of AOAC International. 17th ed. AOAC Int., Gaithersburg, MD.

Cabrita, A. R. J., R. J. B. Bessa, S. P. Alves, R. J. Dewhurst, and A. J. M. Fonseca. 2007. Effects of dietary protein and starch on intake, milk production, and milk fatty acid profiles of dairy cows fed corn silage-based diets. J. Dairy Sci. 90:1429-1439. https://doi.org/10 $.3168 /$ jds.S0022-0302(07)71628-4.

Cai, Y., Y. Benno, M. Ogawa, and S. Kumai. 1999. Effect of applying lactic acid bacteria isolated from forage crops on fermentation characteristics and aerobic deterioration of silage. J. Dairy Sci. 82:520-526. https://doi.org/10.3168/jds.S0022-0302(99)75263-X.

Cao, Y., T. Takahashi, K. Horiguchi, N. Yoshida, and Y. Cai. 2010 Methane emissions from sheep fed fermented or non-fermented total mixed ration containing whole-crop rice and rice bran. Anim. Feed Sci. Technol. 157:72-78. https://doi.org/10.1016/j.anifeedsci .2010 .02 .004 .

Dawson, K. A., M. A. Rasmussen, and M. J. Allison. 1997. Digestive disorders and nutritional toxicity. Pages $633-660$ in The Rumen Microbial Ecosystem. 2nd ed. P. N. Hobson and C. S. Stewart, ed. Blackie Acad. Prof., London, UK.

Dehghan-Banadaky, M., R. Corbett, and M. Oba. 2007. Effects of barley grain processing on productivity of cattle. Anim. Feed Sci. Technol. 137:1-24. https://doi.org/10.1016/j.anifeedsci.2006.11 .021 .

Ferraretto, L. F., P. M. Crump, and R. D. Shaver. 2013. Effect of cereal grain type and corn grain harvesting and processing methods on intake, digestion, and milk production by dairy cows thorough a meta-analysis. J. Dairy Sci. 96:533-550. https://doi.org/10.3168/ jds.2012-5932.

Harmison, B., M. L. Eastridge, and J. L. Firkins. 1997. Effect of percentage of dietary forage neutral detergent fiber and source of starch on performance of lactating Jersey cows. J. Dairy Sci. 80:905-911. https://doi.org/10.3168/jds.S0022-0302(97)76013-2.

Hosoda, K., H. Matsuyama, W. Y. Park, T. Nishida, and M. Ishida. 2006. Supplementary effect of peppermint (Mentha $\times$ piperita) on dry matter intake, digestibility, ruminal fermentation and milk 
production in early lactating dairy cows. Anim. Sci. J. 77:503-509. https://doi.org/10.1111/j.1740-0929.2006.00378.x.

Huntington, G. B. 1997. Starch utilization by ruminants: From basic to the bunk. J. Anim. Sci. 75:852-867. https://doi.org/10.2527/ 1997.753852x.

Krause, K. M., D. K. Combs, and K. A. Beauchemin. 2002. Effects of forage particle size and grain fermentability in midlactation cows. 1. Milk production and diet digestibility. J. Dairy Sci. 85:19361946. https://doi.org/10.3168/jds.S0022-0302(02)74270-7.

Lapierre, H., and G. E. Lobley. 2001. Nitrogen recycling in the ruminant: A review. J. Dairy Sci. 84(Suppl.):E223-E236.

McCleary, B. V., V. Solah, and T. S. Gibson. 1994. Quantitative measurement of total starch in cereal flours and products. J. Cereal Sci. 20:51-58. https://doi.org/10.1006/jcrs.1994.1044.

McDonald, P., R. A. Edwards, J. E. D. Greenhalgh, and C. A. Morgan. 1995. Animal Nutrition. 5th ed. Prentice Hall, Upper Saddle River, NJ, p. 693.

Miyaji, M., H. Inoue, T. Kawaide, M. Tohno, Y. Kamiya, and K. Nonaka. 2017a. Effects of conservation method and crushing method of rice grain on rumen fermentation and nutrient digestibility in steers. Anim. Feed Sci. Technol. 227:75-83. https://doi.org/10 .1016/j.anifeedsci.2017.03.014.

Miyaji, M., H. Matsuyama, and K. Hosoda. 2014. Effect of substituting brown rice for corn on lactation and digestion in dairy cows fed diets with a high proportion of grain. J. Dairy Sci. 97:952-960. https://doi.org/10.3168/jds.2013-7046.

Miyaji, M., H. Matsuyama, and K. Nonaka. 2017b. Effect of ensiling process of total mixed ration on fermentation profile, nutrient loss and in situ ruminal degradation characteristics of diet. Anim. Sci. J. 88:134-139. https://doi.org/10.1111/asj.12610.

Miyaji, M., K. Nonaka, H. Matsuyama, K. Hosoda, and R. Kobayashi. 2010. Effects of cultivar and processing method of rice grain on ruminal disappearance characteristics. Japanese J. Grassl. Sci. 56:13-19. (In Japanese with English abstract).

Mutsvangwa, T., K. L. Davies, J. J. McKinnon, and D. A. Christensen. 2016. Effects of dietary crude protein and rumen-degradable protein concentrations on urea recycling, nitrogen balance, omasal nutrient flow, and milk production in dairy cows. J. Dairy Sci. 99:6298-6310. https://doi.org/10.3168/jds.2016-10917.

NARO (National Agriculture and Food Research Organization). 2006. Japanese feeding standard for dairy cattle. Japan Livest. Ind. Assoc., Tokyo, Japan.

Nishino, N., H. Harada, and E. Sakaguchi. 2003. Evaluation of fermentation and aerobic stability of wet brewer's grains ensiled alone or in combination with various feeds as a total mixed ration. J. Sci. Food Agric. 83:557-563. https://doi.org/10.1002/jsfa.1395.

NRC. 2001. Nutrient Requirements of Dairy Cattle. 7th rev. ed. Natl. Acad. Press, Washington, DC.

Oba, M., and M. S. Allen. 2003. Effects of corn grain conservation method on feeding behavior and productivity of lactating dairy cows at two dietary starch concentrations. J. Dairy Sci. 86:174183. https://doi.org/10.3168/jds.S0022-0302(03)73598-X.

Osman, H. F., B. Theurer, W. H. Hale, and S. M. Mehen. 1970. Influence of grain processing on in vitro enzymatic starch digestion of barley and sorghum grain. J. Nutr. 100:1133-1139.

Peyrat, J., P. Noziere, A. Le Morvan, A. Ferard, P. V. Protin, and R. Baumont. 2014. Effects of ensiling maize and sample conditioning on in situ rumen degradation of dry matter, starch and fibre. Anim. Feed Sci. Technol. 196:12-21. https://doi.org/10.1016/j .anifeedsci.2014.06.017.

Plascencia, A., J. F. Calderon, E. J. DePeters, M. Lopez-Soto, M. Vega, and R. A. Zinn. 1998. Influence of processing on the feeding value of barley for lactating cows. Proc. West. Sec. Am. Soc. Anim. Sci. 49:257-263.

Recktenwald, E. B., D. A. Ross, S. W. Fessenden, C. J. Wall, and M. E. Van Amburgh. 2014. Urea-N recycling in lactating dairy cows fed diets with 2 different levels of dietary crude protein and starch with or without monensin. J. Dairy Sci. 97:1611-1622. https://doi .org/10.3168/jds.2013-7162.

Roe, M. B., C. J. Sniffen, and L. E. Chase. 1990. Techniques for measuring protein fractions in feedstuffs. Pages 81-88 in Proc. Cornell Nutr. Conf., Ithaca, NY. Cornell Univ., Ithaca, NY.

Russell, J. B., and R. J. Wallace. 1997. Energy-yielding and energyconsuming reactions. Pages 246-282 in The Rumen Microbial Ecosystem. 2nd ed. P. N. Hobson and C. S. Stewart, ed. Blackie Acad. Prof., London, UK.

Sholly, D. M., H. Jorgensen, A. L. Sutton, B. T. Richert, and K. E. Bach Knudsen. 2011. Effect of fermentation of cereals on the degradation of polysaccharides and other macronutrients in the gastrointestinal tract of growing pigs. J. Anim. Sci. 89:2096-2105. https://doi.org/10.2527/jas.2010-2891.

Svihus, B., A. K. Uhlen, and O. M. Harstad. 2005. Effect of starch granule structure, associated components and processing on nutritive value of cereal starch: A review. Anim. Feed Sci. Technol. 122:303-320. https://doi.org/10.1016/j.anifeedsci.2005.02.025.

Theurer, C. B., J. T. Huber, A. Delgado-Elorduy, and R. Wanderley. 1999. Summary of steam-flaking corn or sorghum grain for lactating dairy cows. J. Dairy Sci. 82:1950-1959. https://doi.org/10 .3168/jds.S0022-0302(99)75431-7.

Van Soest, P. J., J. B. Robertson, and B. A. Lewis. 1991. Methods for dietary fiber, neutral detergent fiber, and non-starch polysaccharides in relation to animal nutrition. J. Dairy Sci. 74:3583-3597. https://doi.org/10.3168/jds.S0022-0302(91)78551-2.

Waldo, D. R. 1973. Extent and partition of cereal grain starch digestion in ruminants. J. Anim. Sci. 37:1062-1074. https://doi.org/10 $.2527 / \mathrm{jas} 1973.3741062 \mathrm{x}$

Wang, F., and N. Nishino. 2008. Ensiling of soybean curd residue and wet brewers grains with or without other feeds as a total mixed ration. J. Dairy Sci. 91:2380-2387. https://doi.org/10.3168/jds.2007 $-0821$.

Weatherburn, M. W. 1967. Phenol-hypochlorite reaction for determination of ammonia. Anal. Chem. 39:971-974. https://doi.org/10 $.1021 /$ ac60252a045.

Weinberg, Z. G., Y. Chen, D. Miron, Y. Raviv, E. Nahim, A. Bloch, E. Yosef, M. Nikbahat, and J. Miron. 2011. Preservation of total mixed rations for dairy cows in bales wrapped with polyethylene stretch film-A commercial scale experiment. Anim. Feed Sci. Technol. 164:125-129. https://doi.org/10.1016/j.anifeedsci.2010 .11.016.

Xu, C. C., Y. Cai, N. Moriya, and M. Ogawa. 2007. Nutritive value for ruminants of green tea grounds as a replacement of brewers' grains in totally mixed ration silage. Anim. Feed Sci. Technol. 138:228-238. https://doi.org/10.1016/j.anifeedsci.2006.11.014.

Xu, C., Y. Cai, J. Zhang, and H. Matsuyama. 2010. Feeding value of total mixed ration silage with spent mushroom substrate. Anim. Sci. J. 81:194-198. https://doi.org/10.1111/j.1740-0929.2009 .00728.x.

Yang, W. Z., K. A. Beauchemin, and L. M. Rode. 2000. Effects of barley grain processing on extent of digestion and milk production of lactating cows. J. Dairy Sci. 83:554-568. https://doi.org/10.3168/ jds.S0022-0302(00)74915-0.

Yuan, X., G. Guo, A. Y. Wen, S. T. Desta, J. Wang, Y. Wang, and T. Shao. 2015. The effect of different additives on the fermentation quality, in vitro digestibility and aerobic stability of a total mixed ration silage. Anim. Feed Sci. Technol. 207:41-50. https://doi.org/ 10.1016/j.anifeedsci.2015.06.001.

Zinn, R. A., M. Montano, and Y. Shen. 1996. Comparative feeding value of hulless vs covered barley for feedlot cattle. J. Anim. Sci. 74:1187-1193. https://doi.org/10.2527/1996.7461187x. 